\begin{tabular}{c} 
Volume and Issues Obtainable at Center for Sustainability Research and Consultancy \\
Journal of Business and Social Review in Emerging Economies \\
ISSN: 2519-089X (E): 2519-0326 \\
Volume 6: No. 1, March 2020 \\
CSRᄃ \\
Journal homepage: www.publishing.globalcsrc.org/jbsee \\
\hline
\end{tabular}

\title{
Islamic Financial Development and Economic Growth of Emerging Economy of Pakistan; a Panel Data Approach
}

\section{${ }^{1}$ Muhammad Yasir Saeed, ${ }^{2}$ Kashif Hamid, ${ }^{3}$ Muhammad Ahmad Ur Rehman, ${ }^{4}$ Muhammad Nazam}

${ }^{1}$ PhD Scholar at Preston University, Islamabad, Pakistan: mr.yasirsaeed@ gmail.com

${ }^{2}$ Assistant Professor, Institute of Business Management Sciences, University of Agriculture, Faisalabad, Pakistan: kashif.boparai@gmail.com

3 Assistant Professor, FMS, National Textile University, Faisalabad, Pakistan: muhammad@ntu.edu.pk

${ }^{4}$ Assistant Professor, IBMS, University of Agriculture, Faisalabad, Pakistan

\section{ARTICLE DETAILS \\ History \\ Revised format: February 2020 \\ Available Online: March 2020}

\section{Keywords}

Islamic Banks, Islamic

Financing, Islamic Banks

Investments, Islamic banks

Innovation, Economic Growth, $A R D L$

JEL Classification:

O11, A11, A19

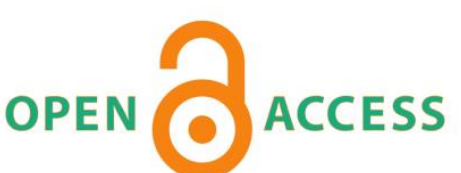

\section{ABSTRACT}

The aim of study is to investigate the dynamic interactions between five pure Islamic banks of Pakistan and economic growth by using Panel ARDL method over the period of 2006-2016. The study elaborates strong confirmation and advocates the significant positive long-run connection with economic growth. However, in short-run, each bank has individual significant positive association with economic growth in its individual capacity. The findings of this study are very encouraging which signify a considerable contribution to recognize how pure Islamic banks activities translated into economic performance of the country. Although prudential regulations of State Bank of Pakistan are quite sound and their legislative structure and policy framing is also equally good but they are required to enhance the number of pure Islamic banks in the country for offering multiple options to clientele in order to promote Islamic economic activities in the country to make Pakistan more prosperous.

(C) 2020 The authors, under a Creative Commons AttributionNonCommercial 4.0

Corresponding author's email address: mr.yasirsaeed@ gmail.com

Recommended citation: Saeed, M. Y., Hmaid, K., Rehman.M.A.U., \& Nazam, M.(2020). Does Islamic Financial Development and Economic Growth of Emerging Economy of Pakistan; a Panel Data Approach. Journal of Business and Social Review in Emerging Economies, 6(1), 197-208

DOI: $10.26710 /$ jbsee.v6i1.1039

\section{Introduction}

The foundation of Islamic banking is positioned on social responsibility system and ethical values. The values like mutual help, fee consent, justice, avoiding fraud, honesty on behalf of parties to indentures, slanting and misstatement of actual facts and denial of injustice or manipulation form the elementary ideologies of the Islamic banking. Hence, moralities of the Islamic banking direct and lead to economic system for achieving the economic prosperity and goodwill. On that premise, the Islamic 
banks turn out to be a doable option for each and every economy regardless of their religion.

Islamic banks play key role: they stimulate savings, encourage Islamic financing, and promote financial stability through financing ethically acceptable ventures (Imam \& Kpodar, 2016) and they avoid speculation, hoarding, interest and contractual uncertainty in the economy. These banks grown exceptionally, as in 1996 only 85 Islamic financial institutions were operating worldwide and then in year 2008 that figure reached to 300 but today this figure has crossed 500 institutions working globally (Boukhatem \& Moussa, 2017). However in a recent study (Hamid and Khurram, 2017) concluded that the Islamic banking has been increasing its dynamic role in the development of economy than conventional banking but still less technical efficient than traditional banking. In start of 2013, the volume of Islamic banks financing covered almost quarter of the market share in Qatar, Bahrain and United Arab Emirates and nearly half in Kuwait and Saudi Arabia. Few international organizations narrated that Islamic banks assets have been increased by $16 \%$ annually from the period year 2003 to 2013. Overall the total increment of assets is reached to $\$ 2,000$ billion in last few years. Currently around 40 million bank customers are benefiting from Islamic banks worldwide (Kammer et al., 2015).

The Islamic banks idea, takes inspiration from Islamic Shariah. As per Islamic Shariah, Islamic banks cannot involve in transactions dealing interest/riba. Further, they cannot involve in Gharar or Maiser element oriented transactions. Moreover, they are also not allowed to deal in any transaction, which is invalid by its subject matter (haram in view of Islam). This banking system emphasis on engendering returns through the tools of investment which are compliant with Shariah rules. Functioning within the domain of Shariah, the Islamic banking operations are made on risk sharing basis that may arise by investment and trading activities through using indentures of several Islamic modes of financing. The permission of trading and prohibition of risk free return, as cherished in Holy Quran in the Verse 2:275, makes the financial activities asset-backed in an Islamic structure with the capability to cause 'value addition' (state bank of Pakistan). There are five principles of Islamic finance the first one is elimination of interest (Riba) second is elimination of gharar (Hazardous transaction) and maysir (gathering wealth through any chance). The third is the firmness that all financing should be returned by secured fixed assets and the fourth is the binding of investment to halal business activities only and the last is sharing in the profit or loss. Previously different studies debated over the issue of either banking development impact positively to economic growth or not. Few studies indicated beneficial impact of banking sector on economic growth (Cull \& Xu, 2005; Shan \& Jianhong, 2006; Galindo et al., 2007; AbuBader \&Abu Qarn, 2008). In contrast, few studies indicated mixed results of both positive and negative effects (Ranciere et al., 2006; Guillaomont-Jeanneney \& Kpodar, 2006). Although enough amount of empirical studies have been conducted to examine the impact of Islamic banking on economic growth ( Abduh et al., 2012; Mosab \& Tabash, 2014) but they all based on samples from developed economies and the findings of these studies is valid for those economies where Islamic banking system play a major role. It has various benefits over instrumental variables cross-sectional method, especially on the subject of controlling measurement of errors and endogeneity in Islamic banking sector indicators related to explanatory variables. The objective of our study is to find the association by focusing on five typical Islamic banks of Pakistan. This decision is warranted by the significance of increasing number of Islamic banks clientele for financing and investment in particular. The second objective of this research is to examine whether Islamic banks alone assure substantial effect on economic performance of country. The first section of the study is a brief introduction of the topic and second section composed of literature review while the third segment demonstrate the data and research methodology then in fourth part results and discussion is reported and finally the conclusion of the study is explained in fifth and last part.

\section{Literature Review}

In this part we have explored latest literature on the linkage between Islamic banks and economic performance. However it has been observed that due to recent developments in banking sector based upon Islamic principles has made more lucrative topic and still have a gain a lot of focus on overall effect of banking sector on economic performance. However, few studies examined the Islamic banks 
characteristics such as mortgages (Ebrahim, 2009), investment financing (Aggarwal \& Yousaf, 2000), banking relationship (Ongena, 2011), stability (Cihak \& Hesse, 2010), risk (Johne et al., 2014), effectiveness (Ongena \& Sendeniz-Yuncu, 2011) and business models (Beck et al., 2013) but only few studies determined the role of Islamic banks in promoting economic performance. Furqani and Mulyani (2009) conducted a first study on Malaysian Islamic banks by taking the quarterly data of the period 1997 to 2005. By examining the relationship among Islamic banks and economic growth they illustrated that Islamic banks long term financing is significantly and positively related to capital accumulation and economic growth. Thus, Islamic banks played effective role being intermediaries' facilitation for transmission of the savings from the agents in an optimistic saving capacity to agents of financing need. They also demonstrated that the economic growth in return supports Islamic banking system to develop and evolve, consequently the link between Islamic banks financing and economic growth is said to be bidirectional. Majid and Kassim (2010) by using the Patrick (1966) supply-leading approach empirically inspected relationship between Islamic banks finance and economic growth and proved that causality direction runs from the Islamic financial development to growth. In contrast to earlier studies Goaied and Sassi (2010) revealed that the link between financial development and economic growth is insignificant in sample size of sixteen countries. The study tried to validate the explicit impact of Islamic banks issued credit to private sector on economic growth by using the GMM method. Further, the study found certain stipulations like, banking sector indicators impact significantly but negatively to economic growth. Furthermore, observations of the study also suggested that the Islamic banking is not supposed to be an exception in MENA countries financial markets, as it appeared weak relationship with economic growth. Abduh et al. (2012) conducted study in Bahrain on conventional and Islamic banking to identify their relationship with development of the banks and economic performance. Results highlighted significant and positive bidirectional link among the Islamic financing and long-term economic growth but interestingly this link was unable to prove in short-run. Moreover, on the other side, conventional banking development is significantly impacted to growth in both short and long-term growth. In Bangladesh Abduh and Chowdhury (2012) investigated the role of Islamic banks in economic growth. By use of cointegration method, the results demonstrated that the Islamic financings shared positive and long run impact on economic growth of Bangladesh. The relationship among variables was neither demandfollowing nor supply-leading; it appeared as a bi-directional connection between the Islamic financial institutions deepening and the growth of economy. Next year Gudarzi Farahani and Dastan (2013) took sample of eight different category countries (Egypt, Malaysia, Qatar, Indonesia, Yemen, UAE, Bahrain and Saudi Arabia) and examined association among the Islamic financial development and their economic performance. The research revealed data from 2000 to 2010 time period and proved that there was positive long term relationship lies between the Islamic financial development and economic growth. Contrary to this, the study conducted by Barajas et al. (2013) indicated weaker financing-growth connection in oil-exporting countries. Further, study suggested that this difference could be obsessed by monitoring and controlling characteristics to financial services, similarly another study conducted by Ayachi et al., (2013) revealed that excessive penetration of the system of Islamic banking affect negatively to economic growth and the major contributors for growth are existing conventional banks. These results of the study based on sample of fifteen countries panel data set from the period 1990-2009. In Jordan Al-Oqool Okab and Bashayreh (2014) attempted to discover the link among the Islamic banks and the economic growth over period of 1980 to 2012. The results indicated that there is a long run bi-directional Granger causality among growth of economy and overall financing of Jordian Islamic banks. That reflects a positive input in Jordanian Islamic banks in order to process financing in economic and social development. However, the relationship appeared to be uni-directional between economic growth and saving deposit that reflected the surplus liquidity trouble as all Jordanian Islamic banking suffered from that. Tabash and Dhankar (2014) found that the connection between Islamic financial institutions and economic growth is positively associated but only in short run. The study used Granger causality test over the data of 1990 to 2008, and stressed for existence of the bidirectional relationship among the Islamic financial development of Islamic financial institutions and economic growth. Moreover, Gheeraert and Weill (2015) evaluated that the macroeconomic 
effectiveness is promted by Islamic banking in a non-linear fashion upto a certain level. In addition to that Imam and Kpodar (2016) also contributed in analysis of linkage between the Islamic banking and economic growth with a sample size of fifty two different economies with the data covering time period of 1990 to 2010. The findings demonstrated that despite relatively small size of Islamic banking in overall size of banks even by controlling several determinants of economic growth, Islamic banking was still positively related to economic growth, study also suggested that those Muslim countries that are currently suffering from decline or low economic growth should expand this division in their banking system further, by modification in legislative, regulations, and other necessary measures as like non Islamic but successful Islamic banking system countries. The study of Kassim (2016); Kalim Mushtaq and Arshed (2016); Abedifar et al. (2016) also revealed same results. Recently Boukhatem and Moussa (2017) used pooled FMOLS regression and co-integration method on the data of fourteen years from 2000 to 2014 of selective MENA countries to determine the dynamic relations among Islamic banking and the process of economic growth. Conclusions of the study led to various findings, although the association between Islamic financing and growth is positive as like other numerous previous studies but when study comes to quality of the connection among Islamic financing of Islamic institutions and growth, the outcomes revealed the existence of a negative impact on interaction, on the other hand Islamic financial practices of institutions has a positive impact on the economy, further study suggest that the underdeveloped institutional framework can diminish this positive effect. Therefore, Islamic banking system required to support infrastructure, employ adequate regulations and legislations to get desired results. Keeping in view previous studies we used set of variables including Islamic Financing, Banks Investment and Bank Innovation for measuring Islamic banking activities in relation to economic growth. The brief description of all variables is as follows.

\subsection{Islamic Financing vs Economic Growth}

The approach of bank financing as the financial transmission strait has turned into more germane in economic theory in last few years. Undoubtedly, an economy is unable to sustain its long term economic growth without stimulating its financing activities that is why previous researches notify the significant relationship between financing and economic growth rate (Guerra, 2017). For this study we have chosen the loan to deposit ratio of Islamic banks to measure their financing capability, as deposits are the main source of bank financing therefore deposits directly have effect on financing (Kassim \& Majid 2008;Thierry, Jun, Eric, Yannick \& Landry, 2016). In a period of the economic expansion Loan to deposit ratio is a tool for banks to manage and control liquidity by controlling the sizes of finance within a definite ratio to deposits. However, this regulation is used to restrain any expansion in financing (Park, Jun \& Lee, 2012).

\subsection{Islamic Banks Investment vs Economic Growth}

Investment and Savings are the two vital macro factors with micro foundation that may play a vital role in economic progression, recent extension of endogenous growth theory and neo classical growth model have highlighted the significance of investment. Causality exists between investment and economic growth (Bint-e-Ajaz \& Ellahi, 2012). In this study we choose the investment to total assets ratio of Islamic banks as proxy because the ratio of investment to total assets explains the investment activities of banks with reference to their total assets as it highlights, how much portion of total assets is used as investment in various activities of financial institutions (State Bank of Pakistan).

\subsection{Islamic Bank Innovation vs Economic Growth}

The innovations and technological revolution has stronger multiplier effect and high degree of scope and economies of scale on banking sector. Innovations involve the quality and variety of banking services, improved efficiency, and new products such as securities as well as electronic banking just as mbanking. Innovation, technological progress and economic growth relationship was evaluated by Adak (2015) and found long run connection among variables. In this study we are taking annual online transactions of banks as proxy of Islamic banks innovation as it is the best determinant of evaluating the progress of branchless banking in Pakistan (Afshan \& Sharif, 2016). 
It is to note that, these variables of the study are identified from different theories of economic growth which are as follows.

\subsection{Theoretical Background Support}

Several economic theories assist in developing the framework of the connection of variables. The association between financial sector and economic progression has been lingering in debates of recent literature of numerous studies. The theories covering the variables and scope of the study are Anticipated Income Theory and Endogenous Growth Theory.

\subsection{Anticipated Income Theory}

The theory was presented in the famous book with a name of "Term Loan and Theories of Bank Liquidity" and it was written by H.V Prochnow in 1945. The theory demonstrated that banking sector must remain engage in various extensive varieties of financing that may consist of long-term and shortterm financing for creating and enhancing economic activities and disbursement of consumer financing keeping in view its fact of repayment for enhancing cash flow. These financing activities boost the liquidity that depends upon likely earnings of Banks and ultimately accelerate the pace of economic development in an economy. In addition to that high surplus reserves of all types of banks contribute in profitability and enhance their capability for financing investment funds.

\subsection{Endogenous Growth Theory}

This theory illustrates that the economic growth is outcome of endogenous factors of organization not the external factors. The endogenous or internal factors are investment decision as well as technological progress or level of innovation that influence the process of economic growth. The theory further narrates that long-run growth generally depends over the policy measures of banks and other financial institutions (Romer, 1994). Furthermore, the endogenous growth model also explains that endogenous factors influence economic progress even on the effect of exogenous productivity. Thus, aim of the study is to identify the link between five pure Islamic bank specific internal factors factors and economic growth. The selected endogenous factors are Islamic financing, Islamic Banks Investment and Banks Innovation.

\section{Summary of Islamic Banking Studies}

\begin{tabular}{|c|c|c|c|c|}
\hline Study & Method & Period & Area & Findings \\
\hline Furquani and Mulyany (2009) & VECM & $2003-10$ & $\begin{array}{l}\text { Malaysia } \\
16 \text { Mena }\end{array}$ & $\begin{array}{l}\text { bi-directional } \\
\text { relationship. } \\
\text { Negative }\end{array}$ \\
\hline Goaied and Sassi (2010) & GMM & $1962-06$ & countries & relationship. \\
\hline $\begin{array}{l}\text { Abduh, M., \& Azmi Omar, } \\
\text { M. (2012) }\end{array}$ & ARDL & $2003-10$ & Indonesia & $\begin{array}{l}\text { bi-directional } \\
\text { relationship. } \\
\text { bi-directional }\end{array}$ \\
\hline Farahani and Sadr (2012) & ARDL & $2000-10$ & Iran & relationship. \\
\hline Farahani and Dastan (2013) & $\begin{array}{l}\text { Panel co- } \\
\text { integration }\end{array}$ & $2000-10$ & $\begin{array}{l}9 \text { Islamic } \\
\text { countries }\end{array}$ & $\begin{array}{l}\text { Positive long-run } \\
\text { relationship. } \\
\text { Negative }\end{array}$ \\
\hline Ayachi et al., 2013 & ARDL & 1990-09 & 15 countries & relationship. \\
\hline Al-Oqool Okab and & & & & bi-directional \\
\hline Bashayreh (2014) & $\begin{array}{l}\text { VECM } \\
\text { co-integration, }\end{array}$ & $1980-12$ & Jordan & $\begin{array}{l}\text { relationship. } \\
\text { Short-run positive }\end{array}$ \\
\hline Tabash and Dhankar (2014) & $\begin{array}{l}\text { Granger causality } \\
\text { Stochastic }\end{array}$ & 1990-08 & Qatar & $\begin{array}{l}\text { relationship. } \\
\text { Positive } \\
\text { relationship up to }\end{array}$ \\
\hline Gheeraert and Weill (2015) & Frontier Approach & $2000-05$ & 70 Countries & $\begin{array}{l}\text { a certain limit. } \\
\text { Positive }\end{array}$ \\
\hline Imam and Kpodar (2016) & GMM & $1990-10$ & 52 Countries & relationship. \\
\hline Abedifar et al., (2016) & Co-integration & 1999-11 & countries & relationship. \\
\hline
\end{tabular}




\begin{tabular}{|c|c|c|c|c|}
\hline $\begin{array}{l}\text { Boukhatem and Moussa } \\
\text { (2017) }\end{array}$ & $\begin{array}{l}\text { Panel co- } \\
\text { integration }\end{array}$ & $2000-14$ & $\begin{array}{l}13 \text { Mena } \\
\text { Countries }\end{array}$ & $\begin{array}{l}\text { Positive } \\
\text { relationship. }\end{array}$ \\
\hline
\end{tabular}

\section{Methodology}

The data of five pure Islamic banks is collected from annual reports (Meezan Bank Ltd, Bank Islami Ltd, Burj Bank Ltd, Al-barka Bank Ltd, Dubai Islamic Bank Ltd) of Sate Bank of Pakistan over the period of 2006 to 2016. To get the best results of the study, data is collected from annual reports of state bank of Pakistan and world development indicators in addition to that authentic proxies are used based on previous research papers. The study used panel data as it observe the behavior of entities and help us in allowing to control for variables that cannot be observed. Moreover, it simplifies the computation and inference, since panel data is of two dimensions, namely cross section and time series that help in minimizing the complications associated with using either of the data, secondly panel data helps in studying the dynamics of changes because it includes repeated study of cross section of observations. In order to find nexus between Islamic financing, banks investment innovation and economic growth, the equation 1 can be estimated as;

$$
E_{i, t}=\beta_{\mathrm{o}}+\beta_{1} I F_{i, t}+\beta_{2} I N_{i, t}+\beta_{3} I N N_{i, t}+\mu_{i t}
$$

Where, Islamic finance is denoted with IF, investment is denoted with IN and Innovation is denoted with INN. The annual GDP growth rate is taken as proxy of economic growth (E).

\subsection{ARDL Model}

ARDL Model is a strong and broad method to deal with variables relationship I(1). Pesaran, Shin and Smith (2001) used the ARDL technique to examine short-run and long-run factors. While, the Mean Group (MG) model is used for resolving the bias owing to heterogeneous slopes in dynamic panel, that offer long-run restrictions to panel by constructing average of long-run restrictions from the ARDL model for individual banks (Pesaran \& Smith 1995). In this model we used fixed effects model right through all analysis just to avoid restriction of the empirical analysis within-bank variations. The general equation for estimating ARDL model is as follows:

$$
\Delta E_{i, t}=\alpha_{0, i}+\alpha_{d, i} t_{i}+\sum_{j=1}^{g} \beta_{1, i} \Delta E_{t-j, i}+\sum_{j=1}^{v} \beta_{2, i} \Delta I F_{t-j, i}+\sum_{j=1}^{i} \beta_{3, i} \Delta \operatorname{In} n_{t-j, i}+\sum_{j=1}^{m} \beta_{4, i} \Delta \operatorname{Inn}_{t-j, i}++\mu_{t, i}
$$

Where i represents cross section, $\alpha_{11, c}$ represents fixed effect and $I F_{t-j, i}$ represents the Islamic finance for cross section $i$.

$$
\theta_{i}=\frac{\beta_{2, i}}{1-\beta_{1, i}}
$$

Is a long-run parameter for the Islamic finance and $\mathrm{MG}$ estimations are:

and

$$
\theta^{0}=\frac{1}{N} \sum_{i=1}^{m} \theta_{c}
$$

$$
\alpha_{1}^{0}=\frac{1}{N} \sum_{i=1}^{N} \alpha_{1}
$$

It is to note that Equation.(1) hold only if a 1 lag is included. The right side of Equation(1), i.e. if $\mathrm{g}=\mathrm{v}=\mathrm{m} . . .=1$. On the other hand if more than single lag is include then a simple formula may be designed. Lag length is chosen on the base of HQ and SI criterion (Hannan \& Quinn, 1979: Schwarz, 1978).

\subsection{Data Analysis and Results}

The results of panel unit root tests including Hadri, ADF-Fisher, PP-Fisher, LLC and IPS are presented in Table 1. Each test is performed at level and first difference of Islamic financing, Investment, Innovation and economic growth. The null hypotheses of unit root can be rejected for PP-Fisher, ADF- 
Fisher, IPS and LLC for all variables while Hadri test accept null hypothesis at $1 \%$ level of significance for Islamic financing, investment and innovation. After taking first difference of all variables, all the tests accept null hypothesis at $1 \%$ level of significance. Hence, we can conclude that all variables are stationary and integrated of order I(1) at first difference.

Table.1 Unit Root Analysis

\begin{tabular}{cllllll}
\hline \multirow{2}{*}{ At Level } & LLC & IPS & $\begin{array}{l}\text { ADF- } \\
\text { Fisher }\end{array}$ & PP-Fisher & $\begin{array}{l}\text { Hadri Z- } \\
\text { Stat }\end{array}$ & $\begin{array}{l}\text { Heteroscedastic } \\
\text { Z-stat }\end{array}$ \\
\hline \hline Growth & -1.40314 & -0.87945 & 8.60205 & 8.40177 & 0.62639 & 0.62639 \\
& $(0.0803)$ & $(0.1896)$ & $(0.5702)$ & $(0.5897)$ & $(0.2655)$ & $(0.2655)$ \\
Lending & 9.8821 & -2.55166 & 0.36319 & 0.44717 & 5.38833 & 4.10807 \\
& $(1.0000)$ & $(0.0054)$ & $(1.0000)$ & $(1.0000)$ & $(0.0000)^{*}$ & $(0.0000)^{*}$ \\
Investment & 3.54852 & -1.37775 & 2.00489 & 2.12298 & 3.86882 & 4.40652 \\
& $(0.9998)$ & $(0.0841)$ & $(0.9963)$ & $(0.9953)$ & $(0.0001)^{*}$ & $(0.0000)^{*}$ \\
Innovation & 0.79766 & 2.08956 & 2.63632 & 2.91704 & 3.50713 & 3.50713 \\
& $(0.7875)$ & $(0.9817)$ & $(0.9887)$ & $(0.9833)$ & $(0.0002)^{*}$ & $(0.0002)^{*}$ \\
First.Diff & & & & & & \\
Growth & -8.92218 & -3.77875 & 65.5343 & 66.1202 & 2.51439 & 2.51439 \\
& $(0.0000)^{*}$ & $(0.0001)^{*}$ & $(0.0000)^{*}$ & $(0.0000)^{*}$ & $(0.0060)^{*}$ & $(0.0060)^{*}$ \\
Lending & -10.0726 & -4.69159 & 38.4842 & 43.9446 & 4.59878 & 7.61629 \\
& $(0.0000)^{*}$ & $(0.0000)^{*}$ & $(0.0000)^{*}$ & $(0.0000)^{*}$ & $(0.0000)^{*}$ & $(0.0000)^{*}$ \\
Investment & -7.59501 & -3.8247 & 50.8445 & 48.791 & 5.03146 & 16.1541 \\
& $(0.0000)^{*}$ & $(0.0001)^{*}$ & $(0.0000)^{*}$ & $(0.0000)^{*}$ & $(0.0000)^{*}$ & $(0.0000)^{*}$ \\
Innovation & -10.9394 & -2.24546 & 35.9194 & 49.3191 & 23.1889 & 23.1889 \\
& $(0.0000)^{*}$ & $(0.0012)^{*}$ & $(0.0001)^{*}$ & $(0.0000)^{*}$ & $(0.0000)^{*}$ & $(0.0000)^{*}$ \\
\hline \hline
\end{tabular}

By considering the results of panel unit root tests, The Panel ARDL test is applied to examine the longrun and short-run dynamics of Islamic bank variables and economic growth. Moreover, the lag length is selected on the base of Schwarz information criterion (Schwarz, 1978) and Hannan-Quinn information criterion (Hannan \& Quinn, 1979). The cross section effects are presented in Table 2 where the long-run model identified that at lag (1) Islamic financing and Islamic banks investments have statistically significant and positive relationship with annual economic growth at $1 \%$ level of significance but in shortrun their impacts on economic growth are insignificant. This highlights the importance of Islamic banks financing and investment practices in the development of economic growth process of Pakistan in longrun perspective, whereas, in short-run perspective bank innovation has statistically significant but in negative relationship with economic growth. For analyzing the detail performance of all five Islamic banks individually, the short-run coefficients diagnostic test is applied and their results are presented in Table 3.

Table.2 Panel ARDL Test

\begin{tabular}{lcccc}
\hline & \multicolumn{2}{c}{ Long Run Equation } & \multicolumn{2}{c}{ Short Run Equation } \\
\cline { 2 - 5 } Variable & Coefficient & Prob. & Coefficient & Prob. \\
\hline \hline Co-int-eq-01 & - & - & -0.65314 & 0.0000 \\
Islamic Financing & 0.44353 & 0.0070 & 0.512797 & 0.1476 \\
$\begin{array}{l}\text { Islamic Banks } \\
\text { Investment }\end{array}$ & 0.50302 & 0.0020 & -0.01909 & 0.9238 \\
Islamic Banks & & & & \\
Innovation & -0.00380 & 0.8785 & 0.068429 & 0.0000
\end{tabular}




\begin{tabular}{llll} 
C & \multicolumn{1}{c}{-} & \multicolumn{1}{c}{-9.81507} & 0.0000 \\
Mean dependent var & -0.008 & S.D. dependent var & 0.4706 \\
S.E. of regression & 0.265986 & Akaike info criterion & 0.4983 \\
Sum squared resid & 1.910214 & Schwarz criterion & 1.5202 \\
Log likelihood & 14.29528 & Hannan-Quinn criter. & 0.8935 \\
level of significane 1\% & & &
\end{tabular}

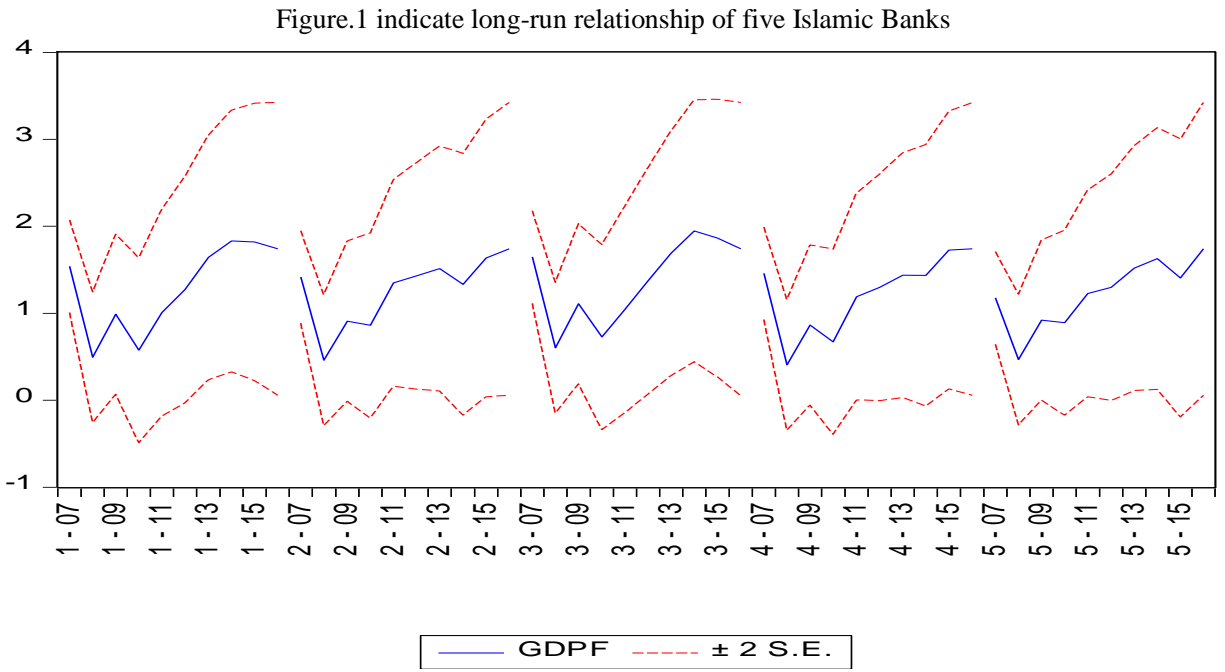

This test indicated individual analysis of all pure Islamic banks in short-run. The Islamic finance of Albarka Bank, Bank Islami and Dubai Islamic Bank have significant positive effect on economic growth at $1 \%$ and $5 \%$ level of significance. Which ensure that the further extension of Islamic banks network and Islamic financing may bring prolific results for economy as in Muslim countries people are recognizing terrible effects of interest (riba) in their businesses and moving rapidly towards availing Islamic finance. The investment of Bank Islami and Dubai Islamic Bank has significant positive effect on economic growth at $1 \%$ level of significance but the impact of bank innovation of all banks on economic growth is significantly positive at $1 \%$ level of significance. Hence, we can conclude that individually all pure Islamic banks of Pakistan (which are currently operating in Pakistan) have significant contribution in development of economic activity for generating economic growth in short-run.

\begin{tabular}{llllll}
\multicolumn{5}{c}{ Table.3 Individual Bank Analysis } \\
\hline \multirow{2}{*}{ Sr.No } & $\begin{array}{l}\text { Pure Islamic } \\
\text { Banks }\end{array}$ & $\begin{array}{l}\text { Islamic } \\
\text { Finance }\end{array}$ & $\begin{array}{l}\text { Banks } \\
\text { Investment }\end{array}$ & $\begin{array}{l}\text { Banks } \\
\text { Innovation }\end{array}$ & COINTEQ01 \\
\hline \hline 1 & Albarka Bank & 0.48999 & -0.7264 & 0.0928 & -0.7481 \\
& & $(0.0000)^{*}$ & $(0.0000)^{*}$ & $(0.0000)^{*}$ & $(0.0003)^{*}$ \\
2 & \multirow{2}{*}{ Bank Islami } & 0.3985 & 0.3080 & 0.0391 & -0.5873 \\
& & $(0.0325)^{*}$ & $(0.0091)^{*}$ & $(0.0000)^{*}$ & $(0.0002)^{*}$ \\
3 & \multirow{2}{*}{ Burj Bank } & -0.6154 & -0.1097 & 0.0557 & -0.8438 \\
& & $(0.0007)^{*}$ & $(0.0079)^{*}$ & $(0.0000)^{*}$ & $(0.0002)^{*}$ \\
4 & Dubai Islamic & 0.7714 & 0.3822 & 0.0897 & -0.7689 \\
& & $(0.0009)^{*}$ & $(0.0005)^{*}$ & $(0.0000)^{*}$ & $(0.0009)^{*}$ \\
5 & \multirow{2}{*}{ Meezan Bank } & 1.5193 & 0.0505 & 0.0646 & -0.3174 \\
& & $(0.4770)$ & $(0.3449)$ & $(0.0000)^{*}$ & $(0.0009)^{*}$ \\
\hline
\end{tabular}

level of significane $1 \%$

Note:Burj Bank has closed now 


\section{Conclusion}

The purpose of this study is to investigate the dynamic interaction among five pure Islamic banks of Pakistan and economic growth by using Panel ARDL method over the period of 2006-2016. The results of the study led to various interesting outcomes, including that the development of key Islamic banking factors stimulate economic development performance. The findings of this study confirm alike conclusions from several studies regarding the significance of Islamic banking practices to promote economic growth. In addition, results of this study indicate that Islamic financing of pure Islamic banks is statistically significant and positively related with economic growth in long-run and these results are consistent with Furqani and Mulyani (2009) and Abduh and Chowdhury (2012). Moreover, in short-run Islamic financing of all the individual banks also has significant positive relationship with economic growth and the same is verified by Tabash and Dhankar (2014). This highlights the vital significance of Islamic financing in Pakistan, now in Islamic banks the Islamic financing is growing rapidly due to its interest free factor but despite of increasing growth of Islamic financing, Pakistan remain characterized by dual banking system where conventional and Islamic banks operate adjacent to each other. The importance of Islamic financing in stimulating economic growth has increasingly caught attention through scarce literature over the link between Islamic financing of Islamic financial institutions and economic growth but unfortunately in Pakistan the number of Islamic banks could not increased from five in last one decade even knowing to the potential of Islamic finance. Therefore, this study highlights the demand for increasing Islamic financial institutions for generating economic growth through interest free financing which is capable to meet the financing requirement within religious norms of financing based on profit and loss sharing. Furthermore, in long-run the Islamic banks investment has statistically significant and positive relationship with economic growth. This specify that the investment activities of Islamic banks with reference to the total assets is increasing gradually and Islamic banks are focusing over their total assets for using them in different financial activities for enhancing the pace of economic growth. In recent years technological progress and innovation has accelerated the rapidity of all business movements towards developmental side and in line with the modern requirements, Islamic banks also adopted different innovative products to attract clientele. The study identified significant positive relationship between Islamic banks innovation and economic growth in short-run and these results are contrary to Adak (2015). In view of this finding we can say branchless banking (online transactions) of Islamic banking is flourished over the last nine years which ultimately impact positively to economic growth. Over all the study found significant positive relationship in long and short-run dynamics of five pure Islamic banks and economic growth and these results are consistent with the (Imam \& Kpodar, 2016; Kassim, 2016; Abedifar et al., 2016; Boukhatem \& Moussa, 2017) but opposite to (Goaied \& Sassi, 2010; Ayachi et al., 2013). The findings of this study are encouraging and signify a considerable contribution to recognize how pure Islamic banks activities translated into economic performance of the country. However, our empirical findings could be improved further by considering few more variables such as size of Islamic banks and depth of Islamic banks activities.

Although prudential regulations of State Bank of Pakistan are quite sound and their legislative structure and policy framing is also equally good but they are required to enhance the number of pure Islamic banks in the country for offering multiple options to clientele in order to promote economic activities in Pakistan.

\section{References}

Abduh, M., \& Azmi Omar, M. (2012). Islamic banking and economic growth: the Indonesian experience. International Journal of Islamic and Middle Eastern Finance and Management, 5(1), 35-47.

Abduh, M., \& Chowdhury, N. T. (2012). Does Islamic banking matter for economic growth in Bangladesh?. Journal of Islamic Economics, Banking and Finance, 8(3), 104-113.

Abedifar, P., Hasan, I., \& Tarazi, A. (2016). Finance-growth nexus and dual-banking systems: Relative importance of Islamic banks. Journal of Economic Behavior \& Organization, 132, 198-215.

Abu-Bader, S., \& Abu-Qarn, A. S. (2008). Financial development and economic growth: The Egyptian 
experience. Journal of Policy Modeling, 30(5), 887-898.

Adak, M. (2015). Technological progress, innovation and economic growth; the case of Turkey. Procedia-Social and Behavioral Sciences, 195, 776-782.

Afshan, S., \& Sharif, A. (2016). Acceptance of mobile banking framework in Pakistan. Telematics and Informatics, 33(2), 370-387.

Aggarwal, R. K., \& Yousef, T. (2000). Islamic banks and investment financing. Journal of money, credit and banking, 93-120.

Al-Oqool, M. A., Okab, R., \& Bashayreh, M. (2014). Financial Islamic banking development and economic growth: A case study of Jordan. International Journal of Economics and Finance, 6(3), 72.

Ayachi Ammar, R., Ben Slama, M., \& Saidane, D. (2013). Does the current practice of Islamic banks encourages growth? Studies in Islamic Economics, 6(12), 57-82

Barajas, M. A., Chami, M. R., \& Yousefi, M. R. (2013). The finance and growth nexus re-examined: Do all countries benefit equally? (No. 13-130). International Monetary Fund.

Beck, T., \& Levine, R. (2004). Stock markets, banks, and growth: Panel evidence. Journal of Banking \& Finance, 28(3), 423-442.

Beck, T., Demirgüç-Kunt, A., \& Merrouche, O. (2013). Islamic vs. conventional banking: Business model, efficiency and stability. Journal of Banking \& Finance, 37(2), 433-447.

Bint-e-Ajaz, M., \& Ellahi, N. (2012). Public-private investment and economic growth in Pakistan: an empirical analysis. The Pakistan Development Review, 61-77.

Boukhatem, J., \& Moussa, F. B. (2017). The effect of Islamic banks on GDP growth: Some evidence from selected MENA countries. Borsa Istanbul Review.

Choi, I. (2001). Unit root tests for panel data. Journal of international money and Finance, 20(2), 249272.

Čihák, M., \& Hesse, H. (2010). Islamic banks and financial stability: An empirical analysis. Journal of Financial Services Research, 38(2-3), 95-113.

Cull, R., \& Xu, L. C. (2005). Institutions, ownership, and finance: the determinants of profit reinvestment among Chinese firms. Journal of Financial Economics, 77(1), 117-146.

Ebrahim, M. S. (2009). Can an Islamic model of housing finance cooperative elevate the economic status of the underprivileged?. Journal of Economic Behavior \& Organization, 72(3), 864-883.

Farahani, Y. G., \& Sadr, S. M. H. (2012). Analysis of Islamic bank's financing and economic growth: Case study Iran and Indonesia. Journal of Economic Cooperation \& Development, 33(4), 1.

Furqani, H., \& Mulyany, R. (2009). Islamic banking and economic growth: Empirical evidence from Malaysia. Journal of Economic Cooperation and Development, 30(2), 59-74.

Galindo, A., Schiantarelli, F., \& Weiss, A. (2007). Does financial liberalization improve the allocation of investment?: Micro-evidence from developing countries. Journal of development Economics, 83(2), 562-587.

Gheeraert, L., \& Weill, L. (2015). Does Islamic banking development favor macroeconomic efficiency? Evidence on the Islamic finance-growth nexus. Economic modelling, 47, 32-39.

Goaied, M., \& Sassi, S. (2010). Financial development and economic growth in the MENA region: What about Islamic banking development. Institutdes Hautes Etudes Commerciales, Carthage (January 2010), 1-23.

Gudarzi Farahani, Y., \& Dastan, M. (2013). Analysis of Islamic banks' financing and economic growth: a panel cointegration approach. International Journal of Islamic and Middle Eastern Finance and Management, 6(2), 156-172.

Guerra, E. A. R. (2017). The economic growth and the banking credit in Mexico: Granger causality and short-term effects, 2001Q1-2016Q4. Economía Informa, 406, 46-58.

Hadri, K., 2000. Testing for stationarity in heterogeneous panel data. Econ. J. 3 (2), 148-161.

Hamid, K., \& Khurram, M.U. (2017). Comparative Analysis of Technical Efficiency for Islamic versus Conventional Banks and its determinants in Pakistan. Journal of Islamic Business and Management, 7(2), 197-210.

Hannan, E. J., \& Quinn, B. G. (1979). The determination of the order of an autoregression. Journal of the 
Royal Statistical Society. Series B (Methodological), 190-195.

Im, K. S., Pesaran, M. H., \& Shin, Y. (2003). Testing for unit roots in heterogeneous panels. Journal of econometrics, 115(1), 53-74.

Imam, P., \& Kpodar, K. (2016). Islamic banking: Good for growth?. Economic Modelling, 59, 387-401.

Jeanneney, S. G., \& Kpodar, K. (2006). Développement financier, instabilité financière et croissance économique. Economie \& prévision, (3), 87-111.

Johnes, J., Izzeldin, M., \& Pappas, V. (2014). A comparison of performance of Islamic and conventional banks 2004-2009. Journal of Economic Behavior \& Organization, 103, S93-S107.

Kalim, R., Mushtaq, A., \& Arshed, N. (2016). Islamic Banking and Economic Growth: Case of Pakistan. Islamic Banking and Finance, 3(1), 14-28

Kammer, M. A., Norat, M. M., Pinon, M. M., Prasad, A., Towe, M. C. M., \& Zeidane, M. Z. (2015). Islamic finance: Opportunities, challenges, and policy options (No. 15). International Monetary Fund.

Kassim, S. (2016). Islamic finance and economic growth: The Malaysian experience. Global Finance Journal, 30, 66-76.

Kassim, S. H., \& Majid, M. S. A. (2008). The role of bank lending in the monetary transmission process of a developing economy: evidence from Malaysia. Savings and Development, 301-319.

Levin, A., Lin, C. F., \& Chu, C. S. J. (2002). Unit root tests in panel data: asymptotic and finite-sample properties. Journal of econometrics, 108(1), 1-24.

Loayza, N., \& Ranciere, R. (2004). Financial development, financial fragility. and Growth\|, Working Paper no WPS3431, Washington DC: World Bank.

Maddala, G. S., \& Wu, S. (1999). A comparative study of unit root tests with panel data and a new simple test. Oxford Bulletin of Economics and statistics, 61(S1), 631-652.

Majid, M., \& Kassim, S. H. (2010). Potential diversification benefits across global Islamic equity markets. Journal of Economic Cooperation \& Development, 31(4).

Ongena, S., \& Şendeniz-Yüncü, İ. (2011). Which firms engage small, foreign, or state banks? And who goes Islamic? Evidence from Turkey. Journal of Banking \& Finance, 35(12), 3213-3224.

Ongena, S., \& Şendeniz-Yüncü, İ. (2011). Which firms engage small, foreign, or state banks? And who goes Islamic? Evidence from Turkey. Journal of Banking \& Finance, 35(12), 3213-3224.

Park, H., Jun, H., \& Lee, D. (2012). Evaluation on the usefulness of the loan-to-deposit ratio regulation.

Patrick, H. T. (1966). Financial development and economic growth in underdeveloped countries. Economic development and Cultural change, 14(2), 174-189.

Pesaran, M. H., \& Shin, Y. (1998). An autoregressive distributed-lag modelling approach to cointegration analysis. Econometric Society Monographs, 31, 371-413.

Pesaran, M. H., \& Smith, R. (1995). Estimating long-run relationships from dynamic heterogeneous panels. Journal of econometrics, 68(1), 79-113.

Pesaran, M. H., Shin, Y., \& Smith, R. J. (2001). Bounds testing approaches to the analysis of level relationships. Journal of applied econometrics, 16(3), 289-326.

Ranciere, R., Tornell, A., \& Westermann, F. (2006). Decomposing the effects of financial liberalization: Crises vs. growth. Journal of Banking \& Finance, 30(12), 3331-3348.

Schwarz, G. (1978). Estimating the dimension of a model. The annals of statistics, 6(2), 461-464.

Shan, J., \& Jianhong, Q. (2006). Does Financial DevelopmentLead'Economic Growth? The Case of China. Annals of Economics and Finance, 7(1), 197.

Tabash, M. I., \& Dhankar, R. S. (2014). Islamic banking and economic growth: An empirical evidence from Qatar. Journal of Applied Economics and Business, 2(1), 51-67.

Thierry, B., Jun, Z., Eric, D. D., Yannick, G. Z. S., \& Landry, K. Y. S. (2016). Causality Relationship between Bank Credit and Economic Growth: Evidence from a Time Series Analysis on a Vector Error Correction Model in Cameroon. Procedia-Social and Behavioral Sciences, 235, 664-671. 